\title{
Changes in the Diet Composition of Transitory Fishes in Coastal Systems, Estuary and Continental Shelf
}

\author{
Paulo T. C. Chaves ${ }^{*}$ and Simone C. Umbria \\ Departamento de Zoologia; Curso de Pós-Graduação em Zoologia; Universidade Federal do Paraná; C. P. 19020; \\ 81531-990; Curitiba - PR - Brazil
}

\begin{abstract}
The feeding habits of five species of teleosts in the southern coast of Brazil were analyzed comparatively between estuary and continental shelf. The displacement between the two sites caused expressive qualitative alterations, the proportion of different items varying from $50 \%$ in the diet of Micropogonias furnieri to $89 \%$ in Isopisthus parvipinnis. In the group of species, $57 \%$ of the items were exclusive to one of the environments and, within the three most common items in the estuary - fish, Polychaeta and plants, only the former was also among the most common items in the shelf. In spite of these differences, the high spectrum of items in both environments and the nature of the item that was most consumed in each one, indicate that there was a certain similarity of patterns between estuary and shelf: Chloroscombrus chrysurus had a carnivorous diet, with a predominance of copepods; M. furnieri and Menticirrhus americanus showed a tendency towards an omnivorous diet; and Cynoscion leiarchus and I. parvipinnis showed a tendency towards ichthyophagy.
\end{abstract}

Key words: Diet; Fish; Estuary; Continental Shelf; Brazil

\section{INTRODUCTION}

Several studies have demonstrated that the diet composition of fish could vary according to the location where the individuals are found, a direct consequence of their alimentary preferences and of prey availability in their environment (Kennish, 1990; Zavala-Camin, 1996). However, these observations were generally made from comparisons between two or more populations, with individuals that reside permanently in different regions. Studies on individuals of a single population, which compare the feeding habits of the individuals in the diverse regions that they inhabit during different occasions, are less common. This type of displacement is common for coastal fish, involving species where the individuals accomplish regular or occasional movements between open sea and estuary (Amanieu and Lasserre, 1982; Bouchereau, 1997). Considering that the species that frequent estuaries are recognized as opportunists with regard to what they ingest (Albaret, 1994), we propose that it is common to find fish in the coastal region that modify their diet depending if they are present in one or another locality. This study analyzes this hypothesis, using five species common to the southern coast of Brazil that throughout their lives, move between estuary and continental shelf.

\footnotetext{
* Author for correspondence
} 


\section{MATERIAL AND METHODS}

The two studied environments are located on the coast of the State of Paraná (Fig. 1). The represented estuary is the Bay of Guaratuba, and here, the collections took place every month, from May 1998 to April 1999, in three areas along an east-west transect. The shelf area is located between the isobars of 8 and 15 meters, between the Itacolomis and Currais Islands, and here, the collections took place every month, from March 1999 to January 2000 (except in October). Two fishing modalities were used: bottom trawl (in the estuary and in the shelf) and gill net (only in the estuary).

Five species, common to the estuary and to the shelf, were chosen, considering their occurrence in the two environments and the expectation of contemplating varied alimentary habits (Table 1). For both environments, the collected fish were transported in ice to the laboratory, where their total length was measured (Table 1). The stomach was removed and fixed in formalyn $10 \%$, for analysis of its content under a stereoscopic microscope. The data were treated by the Frequency of Occurrence method (FO), defined as the percentage of stomachs in which the item is present, in relation to the total number of stomachs with identifiable content. Two of the species were studied inside the Bay by other authors, before the present study: C. leiarchus (Santos, 1997) and $I$. parvipinnis (Chaves et al., 1998). In these cases, the information on the diet in the estuary was used and the source was cited.

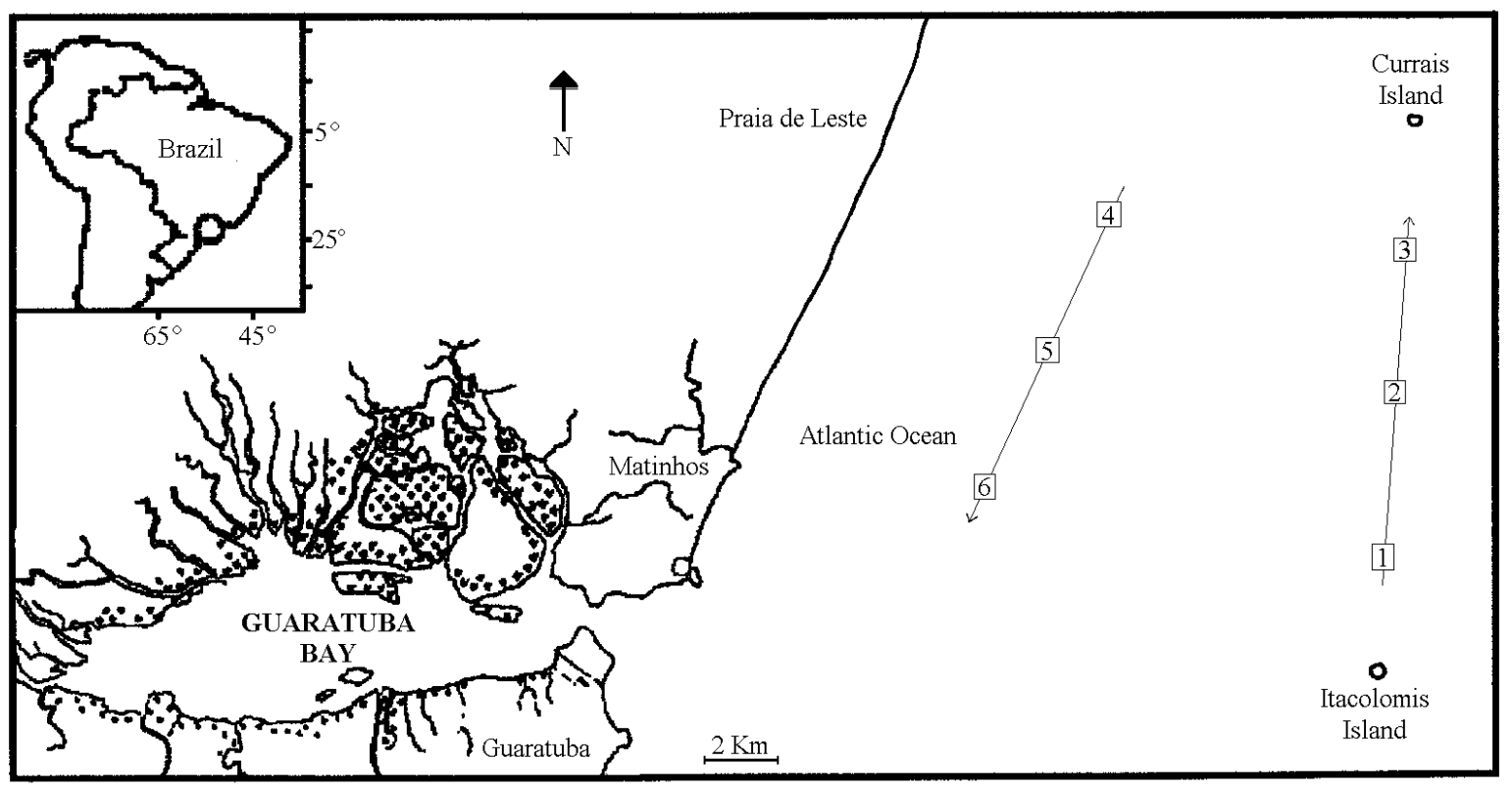

Figure 1 - Map of the sampling area on the coast of the State of Paraná, indicating the estuary (Guaratuba Bay - $25^{\circ} 52^{\prime} \mathrm{S} ; 48^{\circ} 39^{\prime} \mathrm{W}$ ) and the continental shelf (with two transects with six sampling points $\left.25^{\circ} 45^{\prime} \mathrm{S} ; 48^{\circ} 20^{\prime} \mathrm{W}\right)$. The detail shows the position of the region in the Brazilian coast.

\section{RESULTS}

Less than half $(43.3 \%)$ of the items registered in the stomach content were common to both environments, with only fish being found in both for all the species. The other items occurred only in the estuary, or only in the shelf, depending on the species (Table 2). On computation of each species and season separately, we noted that the following items appeared more often with a larger
FO in the estuary than in the shelf: plants, Gastropoda, Isopoda and fish and following items appeared more often with a larger FO in the shelf that in the estuary: Non-Brachyura Decapoda, Bivalvia, diatoms, Brachyura and Copepoda (Fig. 2). Polychaeta anc were found with larger FO in the estuary than in the shelf for 50\% of the analysis and with larger FO in the shelf than in the estuary, for the other $50 \%$. 
Most of the items were exclusive to one of the environments. The following were found only in the estuary: Tanaidacea, Cirripedia, Hidromedusae, Ascidiacea, Insecta, Chlorophyta and Ostracoda; and the following only in the shelf: Chaetognatha, Mysidacea, Porifera, Oligochaeta, Ophiuroidea, Anfioxus, Cumacea and Anomura (Table 2; Fig. 2).

Table 1 - Number (n) and habits of individuals analyzed by species according to the environment, and their total length (TL). The individuals with empty stomachs or those that contained non-identifiable material were omitted.

\begin{tabular}{|c|c|c|c|c|c|}
\hline SPECIES, FAMILY & HABITS $^{1}$ & \multicolumn{2}{|c|}{ ESTUARY } & \multicolumn{2}{|c|}{ SHELF } \\
\hline & & $\mathrm{n}$ & $\mathrm{TL}(\mathrm{mm})$ & $\mathrm{n}$ & $\mathrm{TL}(\mathrm{mm})$ \\
\hline Chloroscombrus chrysurus, Carangidae & $\begin{array}{l}\text { Small size, surface feeder, } \\
\text { plactofagoushabit }\end{array}$ & 22 & $49-127$ & 50 & $40-134$ \\
\hline $\begin{array}{l}\text { Menticirrhus americanus, Sciaenidae } \\
\text { Micropogonias furnieri, Sciaenidae }\end{array}$ & $\begin{array}{l}\text { Great size, bottom feeder, } \\
\text { omnivorous habit }\end{array}$ & 30 & $90-335$ & 120 & $35-336$ \\
\hline & & 90 & $50-250$ & 52 & $139-245$ \\
\hline $\begin{array}{l}\text { Cynoscion leiarchus, } \\
\text { Sciaenidae } \\
\text { Isopisthus parvipinnis, }\end{array}$ & $\begin{array}{l}\text { Great size, bottom feeder, } \\
\text { carnivorous habit }\end{array}$ & $70^{*}$ & $55-435$ & 102 & $45-165$ \\
\hline Sciaenidae & & $130 * *$ & $114-215$ & 138 & $30-198$ \\
\hline
\end{tabular}

${ }^{1}$ Menezes and Figueiredo 1980;

* Santos (1997);

** Chaves et al. (1998).

Table 2 - Items found in the stomach content of the studied species, according to the environment, estuary (E) or continental shelf $(\mathrm{S})$, for all seasons together. +: environment exclusive to an occurrence involving the whole group of species; $x$ : environment exclusive to the species, but not to the group of species; o: environment not exclusive to the species nor to the group of species. Blank spaces indicate that the item does not occur. The code in brackets is a reference for Table 3 .

\begin{tabular}{|c|c|c|c|c|c|c|c|c|c|c|}
\hline \multirow{2}{*}{ Items } & \multicolumn{2}{|c|}{ C. chrysurus } & \multicolumn{2}{|c|}{ M. americanus } & \multicolumn{2}{|c|}{ M. furnieri } & \multicolumn{2}{|c|}{ C. leiarchus } & \multicolumn{2}{|c|}{ I. parvipinnis } \\
\hline & $\mathbf{E}$ & $\mathbf{S}$ & $\mathbf{E}$ & $\mathbf{S}$ & $\mathbf{E}$ & $\mathbf{S}$ & $\mathbf{E}^{*}$ & $\mathbf{S}$ & $\mathbf{E}^{* *}$ & $\mathbf{S}$ \\
\hline Brachyura (BRA) & & & o & $\mathrm{O}$ & o & o & & & & \\
\hline Non-BRA Decapoda (NBD) & & $\mathrm{x}$ & o & o & o & o & & $\mathrm{x}$ & & $\mathrm{x}$ \\
\hline Amphipoda (AMP) & & & $\mathrm{o}$ & o & $\mathrm{x}$ & & & $\mathrm{x}$ & & $\mathrm{x}$ \\
\hline Mysidacea (MYS) & & + & & + & & + & & + & & \\
\hline Copepoda (COP) & o & o & & $\mathrm{x}$ & & $\mathrm{x}$ & & & & $\mathrm{x}$ \\
\hline Tanaidacea (TAN) & + & & + & & + & & & & & \\
\hline Cumacea & & & & + & & + & & & & \\
\hline Ostracoda (OST) & + & & & & + & & & & & \\
\hline Anomura & & + & & + & & & & & & $\mathrm{x}$ \\
\hline Isopoda (ISO) & & & & $\mathrm{x}$ & o & o & $\mathrm{x}$ & & $\mathrm{x}$ & \\
\hline Cirripedia & + & & & & & & & & & \\
\hline Polychaeta (POL) & o & o & $\mathrm{o}$ & $\mathrm{o}$ & o & o & $\mathrm{x}$ & & & \\
\hline Oligochaeta (OLI) & & & & + & & + & & & & \\
\hline Gastropoda (GAS) & & $\mathrm{x}$ & o & o & o & o & & & & \\
\hline Bivalvia (BIV) & & $\mathrm{x}$ & & $\mathrm{x}$ & o & o & & & & \\
\hline Quetognata & & + & & & & & & & & + \\
\hline Anfioxus & & & & + & & & & & & \\
\hline Ascídiacea (ASC) & & & & & & & + & & & \\
\hline Fish (FSH) & o & o & $\mathrm{o}$ & $\mathrm{o}$ & o & $\mathrm{o}$ & o & $\mathrm{o}$ & o & $\mathrm{o}$ \\
\hline Ofiuroidea & & & & + & & & & & & \\
\hline Hidromedusae & & & + & & & & & & & \\
\hline Porífera & & + & & & & & & & & \\
\hline Insecta & & & & & + & & & & & \\
\hline Plants (PLA) & & & $\mathrm{o}$ & $\mathrm{o}$ & o & o & o & o & & $\mathrm{x}$ \\
\hline Diatoms (DIA) & & $\mathrm{x}$ & $\mathrm{x}$ & & o & o & & $\mathrm{x}$ & & $\mathrm{x}$ \\
\hline Clorophyta & & & & & + & & & & & \\
\hline
\end{tabular}

* Santos 1997;

** Chaves et al. (1998). 
The species that had the largest proportion of different items between the two environments was I. parvipinnis: $89 \%$ of the items occurred either in the estuary or in the shelf. Next came $C$. chrysurus (79\%), C. leiarchus (78\%), M. americanus $(63 \%)$ and $M$. furnieri (50\%). Therefore, at least $50 \%$ of the items consumed by all five species were exclusively from one of the two studied environments (Table 2).

Differences were also detected between estuary and shelf in the group of the five items of larger FO for each species (Table 3). In M. americanus and $M$. furnieri, $60 \%$ of them were common to two both environments; in the other species, the percentage of coincidence was smaller. On the other hand, only in these species the main item consumed in the estuary (Non-Brachyura Decapoda or plants, according to the species) was not also the main one in the shelf (where it was fish or Polychaeta); in the other species, Copepoda or fish was the item with a larger FO average in both environments (Table 3). For the group of species, among the three items with larger FO in the estuary - fish, Polychaeta and plants, only the former was with larger FO in the shelf.

The composition of the diet also varied according to the season, because some items had a larger relative participation in the estuary for one period and in the shelf for another. We observed, for example, that 1 . for the group of species, only in the summer (January to March) fish had larger FOs in the estuary than in the shelf; 2 . only in the autumn (April to June) Non-Brachyura Decapoda were registered in the shelf for all the species; 3 . in the summer and in the autumn, plants were found exclusively in the estuary; 4 . only in the winter (July to September) Polychaeta reached larger FOs in the estuary than in the shelf; and 5. only in the spring (October to December) Copepoda were not registered in the estuary.

\section{DISCUSSION}

The diet of the studied species was shown to have a very wide spectrum, both in the estuary environment and in the continental shelf. In fact, it is known that the fishes that frequent estuaries do not have highly specialized diets (Edgar and Shaw, 1995), being generically carnivorous and opportunists (Albaret, 1994).

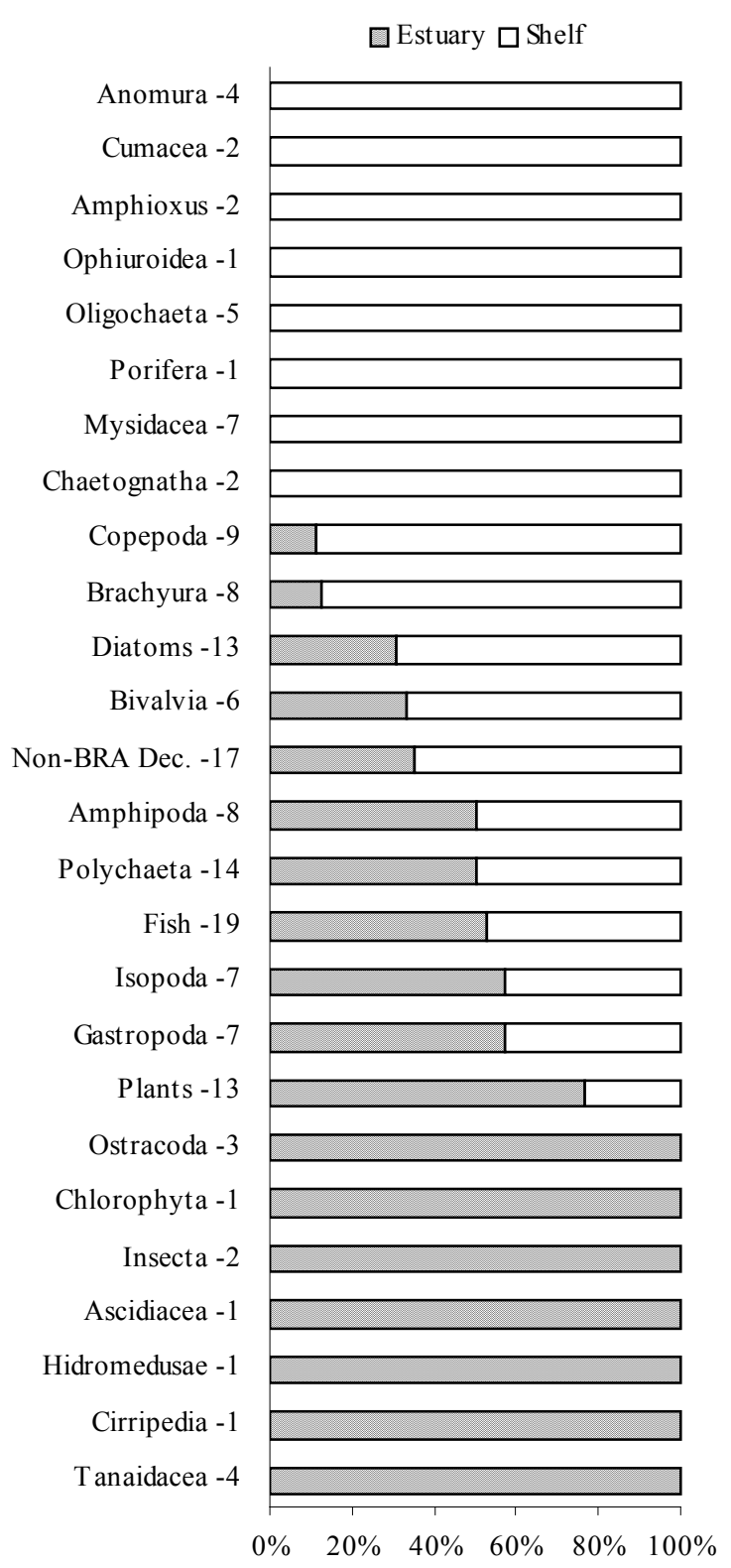

Figure 2 - Percentage of times that each food item reached a larger Frequency of Occurrence in the estuary or in the shelf, considering each species and season as an individual sample (the number of samples is indicated).

From the results, we concluded that the individuals used the trophic resources in a differentiated way whether they were in the estuary or in open sea, and two explanations for this could be proposed. First, that some items were more abundant, and others were actually exclusive for one of the environments.

That was estimated, for example, for plants and Insecta in the bay and for Amphioxus and 
Ophiuroidea in the sea. Because of the varying availability of food, its consumption also differed, as the competition for food exerted an influence on the final diet of the species (Kennish, 1990). And second, that it was common for there to be changes in the alimentary preference of the individuals according to their size, habits and the anatomical structure of the digestive tube, as well as the time of year in which they were found (Zavala-Camin, 1996). For example, the estuary was richer in small-sized individuals of $M$. furnieri and the shelf, with small-sized individuals of $I$. parvipinnis, therefore, it was possible that the difference in diet for these species between the environments was influenced more by the size of the individuals than by prey availability.

Additionally, when looking at the evidence of consumption of different items according to the environment, one should observe that the registration of a given item in either environment is not enough to assure that the diet is similar in both, because within a taxonomic category there may be different species or ecophases. It was not very probable, for example, that the fish consumed by the pelagic species $C$. chrysurus belonged to the same species as those consumed by the demersal species M. americanus.

Table 3 - Decreasing sequence of food items with a larger mean value of Frequency of Occurrence, all the seasons together, according to the species and the environment: E, estuary; S, shelf. Code of the items: see Table 2. C.i.: percentage of items common to the two sequences, independent of their position.

\begin{tabular}{|c|c|c|c|c|c|c|c|c|c|c|}
\hline & \multicolumn{2}{|c|}{ C. chrysurus } & \multicolumn{2}{|c|}{$\begin{array}{c}M . \\
\text { americanus }\end{array}$} & \multicolumn{2}{|c|}{ furn } & \multicolumn{2}{|c|}{ C. leiarchus } & \multicolumn{2}{|c|}{ I. parvipinnis } \\
\hline & $\mathbf{E}$ & $\mathbf{S}$ & $\mathbf{E}$ & $\mathbf{S}$ & $\mathbf{E}$ & $\mathbf{S}$ & $\mathbf{E}^{*}$ & $\mathbf{S}$ & $\mathbf{E}^{* *}$ & $\mathbf{S}$ \\
\hline 1 & $\mathrm{COP}$ & $\mathrm{COP}$ & NBD & FSH & PLA & POL & FSH & FSH & FSH & FSH \\
\hline 2 & PLA & DIA & FSH & BIV & AMP & FSH & PLA & NBD & ISO & NBD \\
\hline 3 & OST & MYS & PLA & BRA & POL & OLI & POL & DIA & - & DIA \\
\hline 4 & FSH & GAS & POL & POL & TAN & AMP & ISO & AMP & - & PLA \\
\hline 5 & POL & FSH & BRA & AMP & NBD & NBD & ASC & MYS & - & - \\
\hline C.i. & \multicolumn{2}{|c|}{$40 \%$} & \multicolumn{2}{|c|}{$60 \%$} & \multicolumn{2}{|c|}{$60 \%$} & \multicolumn{2}{|c|}{$20 \%$} & \multicolumn{2}{|c|}{ - } \\
\hline
\end{tabular}

(*) Santos (1997); (**) Chaves et al. (1998).

With regard to the ecophases of a species and its ecological attributes, one should consider that it is common for the prey to use the estuary and shelf environments in different situations. Thus, many Crustacea have marine planktonic larvae but the adults are bottom dwellers of estuaries, indicating that the taxonomic composition is not sufficient to characterize the ecological attributes of the diet. In spite of these differences, the five species showed a diet with a wide spectrum in both environments and followed a common pattern with regard to the nature of the consumed items. Thus, both in the estuary and in the shelf, $C$. chrysurus fed predominantly on zooplankton, while $C$. leiarchus and $I$. parvipinnis on fish. $M$. americanus, consumed crabs mainly (estuary) or fish (shelf), and M. furnieri, consumes plants in the bay and Polychaeta in the shelf, showing a wider feeding spectrum and characterizing an omnivorous diet that was already well-known for these species.

\section{ACKNOWLEDGMENTS}

We would like to extend our gratitude to the FUNPAR/UFPR, CNPq (Project RAM) and Fundação Araucária for financial supports.

\section{RESUMO}

A alimentação de cinco espécies de teleósteos do litoral sul do Brasil foi analisada comparativamente entre estuário e plataforma continental. Constatou-se que o deslocamento entre os locais acarreta expressivas alterações qualitativas, a proporção de itens diferentes variando de $50 \%$ em Micropogonias furnieri a $89 \%$ em Isopisthus parvipinnis. No conjunto das espécies, $57 \%$ dos itens foram exclusivos de um ambiente ou de outro, e dentre os três mais comuns no estuário - peixes, Polychaeta e vegetais superiores, apenas o primeiro também esteve entre os mais comuns na plataforma. Apesar dessas diferenças, o grande espectro de itens em ambos os 
ambientes e a natureza daquele mais consumido em cada um indicam que há uma certa similaridade de padrões entre estuário e plataforma: em Chloroscombrus chrysurus, dieta carnívora, com predomínio de copépodos; em $M$. furnieri e Menticirrhus americanus, tendência à onivoria; e em Cynoscion leiarchus e I. parvipinnis, tendência à ictiofagia.

\section{REFERENCES}

Albaret, J. J. (1994), Les poissons, biologie et peuplements. In: Durand, J. R.; Guiral, D. and Zabi, S. G. F. (eds.). Environnement et ressources aquatiques de Côte-d'Ivoire. Tome II - Les milieux lagunaires. Paris : Orstom. pp. 239-279.

Amanieu, M. and Lasserre, G. (1982), Organisation et évolution des peuplements lagunaires. Oceanologica Acta, n.sp. (Proceedings International Symposium on Coastal Laggons - Bordeaux, France, September 1981). pp. 201-213.

Bouchereau, J. L. (1997), Biodiversity of tactics used by three Gobiidae (Pisces; Teleostei): Pomatoschisthus minutus (Pallas, 1770), P. microps (Kroyer, 1838), Gobius niger Linnaeus, 1758, to survive in a Mediterranean lagoon environment. Oceanological Studies, (2/3), 153-170.

Chaves, P. T. C.; Rickli, A. and Bouchereau, J. L. (1998), Stratégie d'occupation de la mangrove de la baie de Guaratuba (Brésil) par le sciaenidé prédateur Isopisthus parvipinnis (Teleostei, Pisces). Cah. Biol. Mar., 39 : (1), 63-71.
Edgar, G. and Shaw, C. (1998), The production and trophic ecology of shallow-water fish assemblages in southern Australia. II. Diets of fishes and trophic relationships between fishes and benthos at Western Port, Victoria. J. Exp. Mar. Biol. Ecol., 194, 83-106.

Graham, E. J. and Shaw, C. (1995), The production and trophic ecology of shallow-water fish assemblages in southern Australia. II. Diets of fishes and trophic relationships between fishes and benthos at Western Port, Victoria. J. Exp. Mar. Biol. Ecol., 194, 83-106.

Kennish, M. J. (1990), Ecology of Estuaries. Vol. II. Biological Aspects. CRC Press, Boca Raton, USA. $391 \mathrm{pp}$

Menezes, N. A. and Figueiredo, J. L. (1980), Manual de Peixes Marinhos do Sudeste do Brasil. IV. Teleostei (3). Museu de Zoologia, Universidade de São Paulo. $96 \mathrm{pp}$.

Santos, A. P. (1997), Estrutura populacional, aspectos alimentares e reprodutivos da pescada branca (Cynoscion leiarchus) na região estuarina da Baía de Guaratuba, Paraná. Monografia de Bacharelado, Curso de Ciências Biológicas, Universidade Federal do Paraná. 33 pp.

Zavala-Camin, L. A. (1996), Introdução ao Estudo sobre Alimentação Natural em Peixes. Maringá : EDUEM. 129 pp. 